31. E. O. Bereczki, A. Kárpáti. Teachers' Beliefs about Creativity and its Nurture: A Systematic Review of the Recent Research Literature. Educational Research Review, Vol. 23 (2018). pp. 25-56.

32. S. R. Jonsdottir. Narratives of Creativity: How Eight Teachers on Four School Levels Integrate Creativity into Teaching and Learning. Thinking Skills and Creativity, Vol. 24 (2017), pp. 127-139, 10.1016/j.tsc.2017.02.008

33. Yu-H. Liao, Yi-L. Chen, Hsue-C. Chen, Yu-L. Chang. Infusing Creative Pedagogy into an English as a Foreign Language Classroom: Learning Performance, Creativity, and Motivation. Thinking Skills and Creativity, Vol. 29 (2018), pp. 213-223.

DOI 10.15826/B978-5-7996-3081-2.05

\title{
Creative Speech Making as One of the Goals of Teaching a Foreign Language
}

\author{
Mikhailova Svetlana', Zaitseva Alena ${ }^{2}$ \\ ${ }^{1}$ Institute of the Foreign Languages, State Autonomous Educational Institution \\ of Higher Education of Moscow, Moscow City Pedagogical University, \\ Moscow, Russia \\ ${ }^{2}$ Institute of the Foreign Languages, State Autonomous Educational Institution \\ of Higher Education of Moscow, Moscow City Pedagogical University, \\ Moscow, Russia \\ Corresponding author: Mikhailova Svetlana, jevouslis@mail.ru
}

\begin{abstract}
Creativity is one of the human competencies, the development of which is based on individual aspects. Creative writing as a component of a creative linguistic personality is a set of knowledge about the language, individual characteristics of written production and the ability to creative self-expression. In the study of a foreign language, the formation of a secondary linguistic personality occurs, in our opinion, through speech-creative self-realisation, which determines the linguodidactic potential of creative writing.

Keywords: linguodidactics, creativity, creative writing, secondary linguistic personality, foreign language teaching content
\end{abstract}




\section{Introduction}

The content and goals of learning are dynamic categories; their changes are associated with the development of society and its needs. Information technology in all areas of human activity has led, among other things, to changes in education. Among the factors, that determine the current vector of the development of foreign language education, the modern world's virtualisation and networking play a special role, the signs of an information society indicating the complication of the intercultural communication processes and the ambiguous nature of modern interpersonal integration processes [Tareva, Mikhailova, 2018, 94-95].

In this regard, we consider it important to consider such a concept as a secondary linguistic personality, the creation of which is currently considered as a performance indicator in learning a foreign language. This concept is based on the term linguistic personality. A linguistic personality is objectified by a package of linguo-cognitive, social, pragmatic and psychological characteristics of an individual's personality represented by various speech activities, also through the perception and generation of texts. 'A linguistic personality should be distinguished by communicative activity, value-based and cultural orientation and a desire for creative self-expression at the individual psychological level' [Momotova, 2011, 110].

\section{About linguistic personality}

The generation of a secondary linguistic personality results from mastering a foreign language and immersing in the culture of the people with whom intercultural communication is maintained. At the same time, the secondary linguistic personality acquires the signs and characteristics typical of the speakers of the studied language and is a person's ability to verbal communication with representatives of a foreign language culture in the authentic conditions. The creation of linguistic and cognitive consciousness, which coincides with that possessed by a native speaker, may seem to be a strategic goal of teaching foreign languages and allows an individual to effectively participate in the intercultural communication [Korneeva, 2019].

Let us consider three stages of the creation of a linguistic personality:

At the first stage, the lexicon is generated, the essentials of grammar are mastered and the writing and speaking skills are fostered.

At the next stage, through speech activities and under the influence of various sources of information, the linguistic personality replenishes its 
cultural, ideological, historical and other knowledges. In addition to reproductive thinking, reflexive thinking begins to develop, the stylistic features of speech and text formation rules are mastered. The vocabulary and grammar knowledge of an individual are significantly enriched.

The third stage of development is the consolidation of the acquired skills and the mindset formation, the end result of which is the creation of one's own individual style, a combination of an individual type of thinking and speech habits [Momotova, 2010].

We believe that, among other things, these stages can be applicable to the secondary linguistic personality, since its formation is based on the primary one. In this case, it seems possible to assume that fostering an individual style and, as a consequence, creating a secondary linguistic personality occurs precisely through the speech-creative self-realisation. Since most of the foreign language communication today is maintained on the Internet, where a significant portion of the material is presented in writing, it becomes necessary to place special emphasis on the development of written communicative competence [Medentseva, 2019]. The key goal of teaching writing is to foster written communicative competence, which implies mastery of written signs, content and form of speech creation through writing.

When teaching written speech, such issues are addressed as the formation of graphic automatisms, speech-thinking skills and the ability to formulate a thought according to the written style, expanding knowledge and horizons, mastering culture and intellectual readiness to create the content of a written work, the formation of authentic ideas about the subject content, speech style and graphical form of written text. The end result of teaching written language is the development of students' ability to practically use foreign language writing as a way of communication, cognition and creativity according to the achieved programme level of mastering a foreign language [Vyshentsova et al., 2015].

Speaking about teaching written speech activity, two main terms should be distinguished, writing and written speech. These concepts are interrelated and interdependent but they represent different categories. Written speech is a creative communicative skill consisting of such components as the ability to correctly and compositionally construct and express in writing a speech piece of work built in inner speech, the ability to choose adequate lexical and grammatical units, but the writing skill above all. Writing skill, in turn, means the mastery of the graphic and spelling systems of a language and this mastery 
is a technical component of the writing skill. Thus, the process of teaching written speech activity includes two main tasks, mastering the writing technique, graphic and spelling skills as well as developing the creative communicative ability to express one's thoughts in writing [Nazarova, 2003].

The creation of a speech work contributes to the development of cognitive and speech-thinking activity of students and allows them to show reflection and critical thinking. If the principle of creativity is taken into account when teaching written speech, we can talk about the creative written speech, which is distinguished by original ideas, independent determination of the utterance content, attracting imagination and personal experience including emotional experience, expressing one's own thoughts in relation to the subject of the utterance, combining the language and speech means previously acquired and their use in new and changed communicative situations [Solovtsova, 2016].

Before presenting speech creation as one of the goals in teaching a foreign language, let us dwell on the elements that make up this concept, namely oral activity and creativity.

Oral activity is realised through both oral and written communication and is an active and purposeful activity of an individual regulated by a certain system of motives. To carry out oral activities, a student should have not only certain lexical, grammatical, phonetic and spelling skills but also speech skills aimed at creative activity and involving imagination, emotions and thinking [Maldzigova, 2018].

Let us examine the process of written speech production and the role of a teacher in its course. This process includes three levels, such as motivational-and-incentive, tentative-and-research (analytic-synthetic) and executive.

At the first level, there is a motive manifested in the need to communicate any information. The idea of a future written utterance, needs and motives are formed, and the goal of the speech action is set. At this level, the utterance arrangement is programmed, which requires a student to be able to analyse the situation, draw analogies and also show such creative abilities as detecting and posing a problem, generating ideas and making associations. The teacher's task at this stage is the creation, maintenance and development of the internal motivation of students.

The second level consists of the internal linguistic organisation of the planned utterance. At this stage, adequate words, means and methods of formulating a statement are selected in the internal speech, and phrases are grammatically designed. At the initial stage of teaching foreign language 
written speech, the utterance is first created in the internal speech in the native language and only then in a foreign language. The teacher's mission is to teach how to build the internal speech directly in the studied languages

At the third stage, the written speech production result, which is a text, is fixed. The product is designed according to the spelling rules; its structure and form are edited. Since written speech is considered the most difficult type of speech activity, for its realisation, it is necessary to have clearly stated goals, motives and subconscious mind programming [Makarova, 2016].

\section{Creativity}

Let us consider the concept of creativity. Since in a foreign-language scientific paradigm this concept is denoted by one word, creativity or créativité, we present them in our work as synonyms. Due to the relative novelty of the science of creativity and the complexity of the precise formulation of the concept, definitions vary depending on the research objectives. However, most studies highlight four components of creativity, such as product, process, personality and network. Thus, the result of creative activity is a product that is unique and practically applicable in solving problems; it is created by a person with certain qualities in the course of a creative process divided into several stages. Network factors (family, education, society, culture) have a great influence on the development of personality characteristics.

Let us take a closer look at the creative process stages. The main mechanism of creativity is divergent thinking. By using this type of thinking you can choose several solutions to one problem. There are four stages of the creative process:

1. Preparation period;

2. Gestation period;

3. Period of suddenly being enlightened;

4. Validation period [Gong, 2020].

It should be noted that the creative process stages are similar to the stages of written speech. So, the motivational-incentive level corresponds to the preparation stage, incubation and insight to the tentative-research level, and the realisation and validation coincide with the executive level. In addition, it is believed that creative thinking is directly engaged in writing a text [Lee, Carpenter, 2015].

In the course of researching the concept of speech creation, we found a large number of similar terms, such as linguistic creativity, verbal creativity 
and language creativity. To summarise all these concepts, we can formulate a tentative definition of the term.

Speech creativity is a component of a creative linguistic personality, which is a collection of knowledge about the language, individual characteristics of speech and the ability to creative self-expression, which allows you to create new and original products or transform existing ones. Various forms of language play, metaphor, transposition, hybridisation and approximation can be considered as types of the speech-creating activities [Germasheva, 2016; Pozdeeva, Trofimova, 2017; Klemyat, 2015].

Three stages are singled out in the development of speech-making activity:

The reproductive level passes without the involvement of speech creativity; it involves action following a pattern, the absence of which makes it difficult to complete the task, there is no motivation to perform any creative speech tasks and/or participate in collective creative activity

At the reproductive-productive level, some elements of creativity, which are still based on imitation and following a pattern, begin to emerge. Great independence of the statement is manifested; however, it is not always possible to successfully pursue one's agenda, and a student often needs help.

The productive level of development can be characterised by motivation for speech-creative self-realisation. The speech-making activity outcome at this stage is a statement built by design, which is distinguished by peculiarity and singularity [Nikulina, 2012].

It seems appropriate to put a greater emphasis on the development of speech-making activities of schoolchildren at the level of basic general education, especially in grades $8-9$, since it is at this age that pupils have a need to reflect on their inner state through words [Shilo, 2014]. In this regard, we consider it important to draw more focus toward the psychological and pedagogical characteristics of secondary school students who are taken into account by the key general programme for basic general education.

Adolescence, or the awkward age, as it is also called, falls in the period of secondary school (10-11-14-15-year-old) and means the transition from childhood to an independent adult life. It is during this period that self-awareness begins to develop in schoolchildren; there is a need for reflection, self-affirmation, self-expression and self-determination [Mikhailova, 2017]. The taste for self-analysis typical of this age creates favourable conditions for the development of self-regulation of activities. Unlike younger 
schoolchildren, the adolescent behaviour regulation more often occurs on the basis of internal stimulation [Tolbatova, 2015]. This age can be characterised by the predominance of cognitive motives, the desire to solve problems that go beyond the school professions, the importance of knowledge for the future profession and personal development. The emotional component plays a significant role in the motivation of adolescents [Klepach, Rubtsova, 2019]. The development of creativity plays an important role in adolescence, as it stimulates the self-transformation (transformation de soi) process which takes place at this stage. Creativity contributes to the thinking processes involved in the personality formation; it allows developing and maintaining positive and creative self-esteem, and also gives adolescents more chance to express themselves through their own interests [Barbot, Lubart, 2012]. In adolescence, schoolchildren can be characterised by increased focus on their selfhood (their own 'I'), the desire for self-analysis and creative activity [Solovtsova, 2016].

Let us note the features of today's students. According to the theory of generations, modern schoolchildren belong to generation $\mathrm{Z}$, i. e. those born after 2000. The key distinguishing feature of this generation is that they perceive most information visually. At the same time, $98 \%$ of young people use the Internet every day [Google:... 2017]. In addition, Generation Z has a shorter attention span to one piece of information than the previous generation. In this regard, the content they perceive should be fast, ephemeral, interactive [Kucherikhin, 2018].

In this regard, we consider it vital to emphasise the importance of a personality-oriented approach. One of the ways to objectify this approach is to realise the joint fruitful creative activities of the teacher and students. This type of activity contributes to fostering the creativity of a linguistic personality by improving its psychological and linguistic characteristics. The development of creative skills involves shifting away from traditional reproductive methods of education aimed at assimilating subject knowledge in favour of innovative and creative learning, in which educational and subject activity is only a tool, and the key emphasis is on character education.

Subject to the conditions of realisation and design, the joint creative activities of the teacher and students help expand the motivational sphere of the latter, reveals educational activity as a way of self-education and self-improvement, stimulates the cognitive-intellectual sphere of the linguistic personality and prepares it for the joint intellectual interaction. The teacher's personality ceases to be closed and 'intolerant of wrangling' and the transition 
to sincerity, openness and trust in the pedagogical process is carried out. The recognition by adults of the student's independence and responsibility fall abreast of the development of the value-semantic component of his/her linguistic personality. Through the use of personal experience, the thoughts and initiatives of students, each of them takes an active part in the learning process. The use of self- and mutual control has a positive effect on the creation of the reflective and emotional qualities of a linguistic personality, which contributes to self-exploration.

The organisation of joint productive and creative activities has a positive effect on the emotional atmosphere in the classroom, helps reduce the level of anxiety, and provides space for pupil's emotional manifestations. Internal motives associated with creativity, interaction and cooperation come to the fore, which facilitates the participation in the process of learners with different levels of intellectual and psychological development [Momotova, 2010]. A student-centred approach regards the personality of the learner as of paramount importance thus giving the teacher the role of assistant. It takes into account the individual differences of students in origin, interests and abilities, assumes active participation of everyone in the learning process, decision-making, and lets him/her make a choice. This approach encourages student collaboration and co-creation. It creates conditions for the holistic development of the student's personality, increases the efficiency of the educational process, helps increase the motivation, and increases the amount of acquired knowledge [Rosenberg, 2008]. This approach comes into use, among other things, through the creation of personal orientation texts that reflect the interests of our learners, which can be reflected in sample programmes for teaching a foreign language in schools.

The result of creative written speech is a written statement with a greater degree of self-expression by a learner and is distinguished by original ideas and the manifestation of an emotional-personal attitude. By studying this type of written speech, a student can acquire creative personal qualities, for example, the ability to think creatively, find out-of-the-box solutions to communicative problems, be sociable and ready for interpersonal and intercultural interaction [Solovtsova, 2016].

Emphasis should be put on the pan-European regulatory documents that determine the content of written foreign language competences. Having determined for ourselves, as a result of the analysis of the federal state educational standards of basic general education, that by the end of the 9th grade, 
schoolchildren should be proficient in a foreign language at the A2/A2 + level, we will consider the writing skills that presuppose possession of this level.

The competencies of this section at level A2 fall into two categories, i. e. writing a written statement (general writing skills, production écrite générale) and creative writing (écriture créative). The A2 level of mastering general writing skills expects from students the ability to compose a series of expressions and phrases with simple linking words. Creative writing involves skills, such as description of everyday aspects of your network, such as people, places, work or school, in related phrases; making up a short and simple description of events that took place, activities carried out, personal experiences; composition of a sequence of phrases about your family, living conditions, education, work; writing fictional biographies and short poems about people [CECRL, 2020].

In the course of our research, we also studied the educational standards of a number of Francophone countries. Thus, the curriculum of Francophone Switzerland (Plan d'études romand) includes such general educational competence as creative thinking (pensée créatrice) focussed on developing ingenuity, fantasy, imagination and flexibility in addressing various issues. This competency is implemented in the form of the components as follows:

1. To develop unconventional thinking (développement de la pensée divergente): to use a variety of sources of inspiration; to benefit from a change; to express your own ideas in new forms; to make experiments with associations; to accept risk and the unknown; to get rid of prejudices and stereotypes.

2. To comprehend the emotional aspects of oneself (reconnaissance de sa part sensible): to give rein to dreams and imagination; to identify and appreciate the original aspects of the creation; to identify and express your own emotions; to find harmony in intuition, logic and one's own emotions, although often contradictory.

3. To foster inventiveness (concrétisation de l'inventivité): to capitalise on your own inspiration and ideas; to take on new ideas and use new paths; to choose inventive strategies and techniques; to represent yourself and use various ways of self-realisation.

It should be noted that, according to the Swiss methodologists, when studying a foreign language, this competence develops primarily through writing personal texts (textes personnels) [Plan détudes romand, 2020].

Creative writing in the format of the author's text of a personal orientation is recorded as a mandatory component of the Olympiad for schoolchildren in foreign languages, for example, French [Bubnova, 2017]. 


\section{Conclusion}

Thus, the obligatory nature of teaching speech creativity in a foreign language as a way of creating the secondary linguistic personality of students and the development of their creative thinking is undeniable. Creativity is one of the human competencies, the development of which is based on individual aspects. The creative process, the result of which is a creative product, is implemented by a creative personality. In this system, the role of the teacher, classroom atmosphere and chosen working methods are important. In learning foreign languages, techniques, such as brainstorming, language play, role-playing, creating simulations, creative writing [Mudrochova, 2015], plurigraphy and collaborative network creativity can be used [Mikhailova and Petrov, 2019; Mikhailov, 2019]. The products of creative written speech can be considered original captions to drawings, posters, photographs, slides, comics, poems, greeting cards of unusual content, characteristics of fictional characters, letters from a 'reader' to the author of a book read or to his favourite artist, short fictional stories, programmes etc., scenarios of holidays or other school events, a description of their impressions of what they saw or heard, small essays with reasoning about a specific question or problem, demonstrating the student's desire for self-expression and attracting him/her not only to the educational but also personal life experience, emotions, imagination [Solovtsova, 2016].

To summarise the above, we will designate speech as one of the goals of teaching a foreign language in view of its linguodidactic potential and significance in the process of becoming a secondary linguistic personality.

\section{Conflict of Interest}

The authors have no conflict of interest to declare.

\section{References:}

1. G. I. Bubnova. Metodicheskiye rekomendatsii po razrabotke zadaniy i trebovaniy k provedeniyu shkol'nogo i munitsipal'nogo etapov vserossiyskoy olimpiady shkol'nikov v 2017/2018 uchebnom godu po frantsuzskomu yazyku [Methodological recommendations for the development of tasks and requirements for local and municipal rounds of the Russian Olympiad in French for schoolchildren in the 2017/2018 academic year] (2017). http://vserosolymp.rudn.ru/mm/mpp/files/fr-sm-2018.pdf (Accessed 11 August 2020).

2. Y. V. Vyshentsova, N. B. Gaylis, N. G. Degtyar, I. M. Shitiva. Ispol'zovaniye tvorcheskikh zadaniy pri obuchenii pis'mennoy rechi na urokakh inostrannogo yazyka 
[The use of creative tasks in teaching written speech in foreign language lessons]. Filosofiya obrazovaniya, psikhologiya i pedagogika: teoreticheskiye i prakticheskiye aspekty sovremennykh issledovaniy. Sbornik statey XVIII Mezhdistsiplinarnoy nauchno-prakticheskoy konferentsii aspirantov i soiskateley [Philosophy of education, psychology and pedagogy: theoretical and practical aspects of modern research. Collection of articles of the XVIII Interdisciplinary scientific and practical conference of graduate and postgraduate students]. FGAOU DVO APKPPRO, Moscow (2015), pp. 25-31.

3. T.M. Germasheva. Lingvokreativnyy diskurs: k postanovke problemy [Linguocreative discourse: to the formulation of the problem]. Diskurs-Pi, № 3-4 (2016), pp. 166-172.

4. T. A. Korneeva. Inostrannyy yazyk kak sredstvo formirovaniya vtorichnoy yazykovoy lichnosti [Foreign language as a means of forming a secondary linguistic personality]. Epokha nauki, No. 20 (2019), pp. 533-536.

5. L. Y. Klemyat. Lingvokreativnaya deyatel'nost' i yeye proyavleniya v internet-diskurse [Linguocreative activity and its manifestations in the Internet discourse]. Uchenyye zapiski UO "VGU im. P. M. Masherova”: sbornik nauchnykh trudov [Scientific notes of the UO "VSU named after P. M. Masherov" : collection of scientific papers], № 20 (2015), pp. 206-213.

6. Y.V. Klepach, T. V. Rubtsova. Osobennosti motivatsii uchebnoy deyatel'nosti podrostkov [Features of motivation of educational activity of adolescents]. Pedagogical Review, № 6(28) (2019), pp. 63-72.

7. V.V. Kucherikhin. Pokoleniye $Z$ - pokoleniye "pryamogo efira" i "istoriy" [Generation Z - the generation of "live broadcast" and "stories"]. Cherepovetskiye nauchnyye chteniya 2017 [Cherepovets Scientific Readings 2017]. Izd-vo Cherepovetskiy gosudarstvennyy universitet, Cherepovets (2018), pp. 70-72.

8. Y.A. Makarova. Osobennosti protsessa porozhdeniya inoyazychnogo pis'mennogo vyskazyvaniya kak tvorcheskogo protsessa [Features of the process of generating a foreign language written utterance as a creative process]. Innovatsionnaya nauka, № 2-4 (14) (2016), pp. 81-86.

9. Z. A. Maldzigova. Ot vnutrenney rechi k aktivnoy rechevoy deyatel'nosti [From internal speech to active speech activity]. Problemy sovremennogo pedagogicheskogo obrazovaniya [Problems of modern pedagogical education], № 60-3 (2018), pp. 206-209.

10. N.P. Medentseva. Vliyaniye sovremennykh media na vybor metodiki obucheniya pis'mennoy rechi [Influence of modern media on the choice of teaching methodology in writing]. Problemy i perspektivy razvitiya obrazovaniya: materialy XI Mezhdunar. nauch. konf. [Problems and prospects for the development of educa- 
tion: proceedings of the XI International scientific conference] (Krasnodar, August 2019). Novatsiya, Krasnodar (2019), pp. 1-3.

11. S. V. Mikhaylova. Seteratura kak innovatsiya vo frankoyazychnom kul'turnom nasledii [Networking as an innovation in the French-speaking cultural heritage]. Chelovek i yego yazyk: diakhroniya i sinkhroniya, novyye idei i podkhody. materialy XIX Mezhdunarodnoy nauchnoy konferentsii Shkoly-Seminara im. L. M. Skrelinoy: sbornik statey [Man and his language: diachrony and synchrony, new ideas and approaches. Proceedings of the XIX International Scientific Conference of the School-Seminar named after L. M. Skrelina: collection of articles]. Karel'skiy naunchyy tsentr RAN, Petrozavodsk (2019), pp. 322-331.

12. S. V. Mikhaylova, V.V. Petrov. Écriture(s) plurielle(s) kak istoricheskaya predposylka frankoyazychnoy seteratury [Écriture(s) plurielle(s) as a historical prerequisite for the French-speaking network] Yazyk i deystvitel'nost'. Nauchnyye chteniya na kafedre romanskikh yazykov im. V.G. Gaka. Sbornik statey po itogam IV mezhdunarodnoy konferentsii [Language and reality. Scientific readings at the Department of Romance Languages named after V.G. Gak. Collection of articles on the results of the IV international conference]. OOO “Izdatel'stvo Sputnik+", Moscow (2019), pp. 290-297.

13. O.B. Mikhaylova. Kharakteristiki proyavleniy kreativnosti i innovatsionnosti u uchashchikhsya sredney i starshey shkoly [Characteristics of manifestations of creativity and innovation among students of secondary and high school]. Vestnik RUDN. Seriya: Psikhologiya i pedagogika [Bulletin of RUDN. Series: Psychology and Pedagogy], № 1 (2017), pp. 76-87.

14. Y.G. Momotova. Sovmestnaya produktivnaya tvorcheskaya deyatel'nost' kak integratsiya psikhologicheskikh usloviy razvitiya yazykovoy lichnosti [Joint productive creative activity as the integration of psychological conditions for the development of a linguistic personality] Bulletin of VyatSU, № 2-1 (2012), pp. 146-150.

15. Yu. G. Momotova. Ponyatiye i struktura yazykovoy i vtorichnoy yazykovoy lichnosti [Concept and structure of linguistic and secondary linguistic personality. Bulletin of VyatSU, № 2-3 (2011), pp. 109-114.

16. G. I. Nazarova. Didakticheskiye i psikhologo-lingvisticheskiye faktory postroyeniya sistemy obucheniya pis'mennoy rechi [Didactic and psychological and linguistic factors of constructing a system of teaching writing]. Bulletin of TGSPU. № 1 (2013), pp. 108-112.

17. T. G. Nikulina. Metodicheskaya model' rechetvorcheskogo razvitiya shkol'nikov [Methodical model of speech-creative development of schoolchildren]. Bulletin of TSPU, № 11 (126) (2012), pp. 212-214. 
18. I. M. Pozdeyeva, G. S. Trofimova. Inoyazychnoye rechetvorchestvo kak napravleniye $\mathrm{v}$ obuchenii shkol'nikov inostrannomu yazyku [Foreign language oratory as a direction in teaching schoolchildren a foreign language]. Kazanskaya nauka, № 5 (2017), pp. 179-182.

19. O.F. Rozenberg. Psikhologicheskiye printsipy lichnostno oriyentirovannogo podkhoda [Psychological principles of a personality-oriented approach]. Psikhopedagogika v pravookhranitel'nykh organakh [Psychopedagogy in law enforcement agencies], № 2(33) (2008), pp. 68-72.

20. E. I. Solovtsova. Didakticheskiye i psikhologo-lingvisticheskiye faktory postroyeniya sistemy obucheniya pis'mennoy rechi [Didactic and psychological-linguistic factors of constructing a system of teaching written speech]. Sovremennoye dopolnitel'noye professional'noye pedagogicheskoye obrazovaniye [Modern additional professional pedagogical education], № 1 (2016), pp. 61-70.

21. E. G. Tareva, S. V. Mikhaylova. Russkiy yazyk v epokhu global'nykh obrazovatel'nykh transformatsiy [Russian language in the era of global educational transformations]. Obucheniye frantsuzskomu i russkomu yazykam kak inostrannym. Lingvisticheskiye i didakticheskiye aspekty [Teaching French and Russian as foreign languages. Linguistic and didactic aspects]. Yazyki Narodov Mira; TEZAURUS, Moscow (2018), pp. 93-104.

22. E. V. Tolbatova. Kharakteristiki proyavleniy kreativnosti i innovatsionnosti u uchashchikhsya sredney i starshey shkolym [Characteristics of manifestations of creativity and innovation among students of secondary and high school]. Nauchnyy rezul'tat. Pedagogika i psikhologiya obrazovaniya [Scientific result. Pedagogy and psychology of education], № 1(3) (2015), pp. 67-74.

23. T. B. Shilo. Osobennosti razvitiya verbal'noy kreativnosti u shkol'nikov [Features of the development of verbal creativity in schoolchildren]. Chelovek i obrazovaniye [Man and Education], № 2(39) (2014), pp. 157-161.

24. B. Barbot, T. Lubart. Adolescence, créativité et transformation de Soi. Enfance, № 3 (2012), pp. 292-312.

25. CECRL-Cadre européen commun de référence pour les langues: apprendre, enseigner, évaluer. https://rm.coe.int/16802fc3a8 (Accessed 24 April 2020).

26. Google: issledovaniye privychek i povedeniya rossiyskoy molodezhi onlayn [Google: research of habits and behavior of Russian youth online] (2017). https:// adindex.ru/news/researches/2017/03/10/158475.phtml (Accessed 28 April 2020).

27. S. Gong. On the Cultivation of Middle School Students' Creativity. English Language Teaching, Vol. 13, № 1 (2020), https://files.eric.ed.gov/fulltext/EJ1239141. pdf (Accessed 11 August 2020). 
28. S. Lee, R. Carpenter. Creative thinking for 21 st century composing practices: Creativity pedagogies across disciplines. Across the Disciplines, № 12(4) (2015), http://wac.colostate.edu/atd/performing_arts/lee_carpenter2015.cfm (Accessed 11 August 2020).

29. R. Mudrochova. Teaching Writing in French at University and Students' Creativity as its Component. TOJET (August 2015), pp. 524-529.

30. Plan d'études romand. https://www.plandetudes.ch/home (Accessed 24 April 2020).

DOI 10.15826/B978-5-7996-3081-2.06

\title{
Implementation Features and Development Prospects in Distance Learning of Russian as a Foreign Language (RFL) at Pre-University Faculty
}

\author{
Alimova Maria', Gutorova Daria², Prokopova Ivanna \\ ${ }^{1}$ RUDN University, Moscow, Russia \\ ${ }^{2}$ Plekhanov Russian University of Economics, Moscow, Russia \\ ${ }^{3}$ Pushkin State Russian Language Institute, Moscow, Russia \\ Corresponding author: Alimova Maria, alimova.mv@yandex.ru
}

\begin{abstract}
The aim of this article is to describe the experience of e-learning of Russian as a Foreign Language (RFL) at the Pre-University Faculties based on the examples of three Russian educational organizations of higher education. The authors summarized the practical experience of Pre-University Faculties shift to e-learning in the period of the COVID-19 spread; the article also makes analysis of specific features characterizing this shift, describes the specifics of shifting the lessons into a digital mode and also examines the prospects of development of digital environment for the RFL Pre-University Faculty students. On the basis of the analysis, the authors describe the most common difficulties which faced both students and teachers. The results of this research show that distant learning became the only available instrument of the educational process functioning in the period of self-isolation when it was impossible to conduct face-to-face lessons. During the pandemic, the organization of the educational
\end{abstract}

